\title{
PERBEDAAN KONSENTRASI DAN JENIS PESTISIDA NABATI TERHADAP Plutella xylostella PADA TANAMAN KUBIS UNGU (Brassica oleracea L.)
}

\author{
Shinta Sonia' ${ }^{1)}$, Toto Siswancipto ${ }^{2)}$, dan Tintin Febrianti ${ }^{2)}$ \\ 1) Mahasiswa Fakultas Pertanian Universitas Garut \\ ${ }^{2)}$ Dosen Fakultas Pertanian Universitas Garut \\ E-mail:tin2fb@gmail.com
}

\begin{abstract}
ABSTRAK
Percobaan dilaksanakan di Desa Pasawahan, Kecamatan Tarogong Kaler, Kabupaten Garut. Dengan ketinggian tempat 758 mdpl. Tipe curah hujan berdasarkan kriteria (Schmidt dan Ferguson, 1951) termasuk tipe curah hujan C dengan nilai $Q=48,6 \%$ yaitu agak basah. Percobaan dilaksanakan pada bulan Juni sampai September 2017. Metode penelitian digunakan dalam penelitian adalah eksperimental dengan menggunakan Rancangan Acak Kelompok (RAK) pola faktorial $4 \times 3$ dengan 3 ulangan. Faktor pertama perlakuan konsentrasi (K) terdiri atas 4 taraf yaitu: $\mathrm{k}_{1}=4 \mathrm{ml} /$ liter air, $\mathrm{k}_{2}=8 \mathrm{ml} /$ liter air, $\mathrm{k}_{3}=16 \mathrm{ml} /$ liter air, $\mathrm{k}_{4}=$ $32 \mathrm{ml} /$ liter air. Faktor kedua jenis pestisida $(\mathrm{J})$ terdiri atas 3 taraf yaitu; $\mathrm{j}_{2}=$ larutan ekstrak daun suren,: $\mathrm{j}_{1}=$ larutan ekstrak daun menngkudu, $\mathrm{j}_{3}=$ larutan ekstrak daun pepaya.Hasil penelitian menunjukan terjadi interaksi antara konsentrasi dengan jenis pestisida nabati terhadap jumlah hama pernamanan dan intensitas serangan hama pertanaman. Kombinasi perlakuan $\mathrm{k} 4 \mathrm{j} 2$ menunjukan jumlah hama dan interaksi serangan hama pertanaman yang paling rendah. Secara mandiri konsentrasi $32 \mathrm{ml} / \mathrm{L}$ air baik terhadap jumlah hama pertanaman dan intensitas serangan hama pertanaman, dan secara mandiri jenis ekstrak daun suren berpengaruh baik terhadap penekanan jumlah populasi dan intensitas serangan hama Plutella xylostella L.
\end{abstract}

Kata Kunci : Jenis dan Konsentrasi, Pestisida Nabati, Plutella xylostella L, Kubis Ungu

\section{PENDAHULUAN}

Kubis atau kol merupakan salah satu jenis sayuran yang berasal dari daerah subtropis. Komposisinya kubis merupakan tanaman yang banyak mengandung vitamin, mineral, karbohidrat dan protein yang cukup bagi tubuh manusia. Selain 
itu kubis merupakan komoditas tanaman sayuran yang memiliki nilai ekonomi tinggi meskipun nilai jualnya sangat dipengaruhi oleh kualitas hasil, khususnya penampilan produk. Kubis ungu merupakan sejenis tanaman sayuran yang biasa digunakan untuk pelengkap salad. Kubis ini mengandung air, protein, lemak, karbohidrat, serat, kalsium, fosfor, besi, natrium, kalium, vitamin, sianohidroksibutena dan antosianin (Regina, 2007).

Budidaya kubis seringkali menghadapi banyak kendala dalam meningkatkan produktivitas baik dari segi kuantitas maupun kualitas. Salah satu masalah utamanya yaitu adanya serangan OPT (Organisme Pengganggu Tanaman). Salah satu OPT yang dapat merusak tanaman kubis adalah hama Plutella xylostella L yang merupakan hama utama pada tanaman kubis. Serangga ini merupakan jenis hama yang sangat rakus, pada tingkat tertentu dapat merugikan cukup besar dan dapat menyebabkan gagal panen apabila tidak dilakukan pengendalian. Penggunaan pestisida merupakan salah satu cara untuk mengendalikan serangan dari hama Plutella xylostella L. Namun penggunaan pestisida sintetik yang tidak bijaksana dapat merusak lingkungan dan kesehatan manusia. Penggunaan pestisida kimia sintetis untuk mengendalikan hama mempunyai dampak negatif terhadap komponen ekosistem lainnya seperti terbunuhnya musuh alami, resurgensi dan resistensi hama serta pencemaran lingkungan karena residu yang ditinggalkan (Kishi et al., 1995).

Penggunaan pestisida nabati merupakan salah satu cara dalam menggantikan peran pestisida kimia. Karena akhir-akhir ini perhatian terhadap pestisida nabati makin besar dengan semakin diketahuinya pengaruh pestisida sintetik (kimiawi). Pestisida tersebut antara lain yaitu daun pepaya, nimba, kirinyuh, suren, sirsak, cengkeh, kemangi, serai, kirinyuh, mengkudu, mindi. Daun tersebut terkenal sebagai obat tradisional. Bahan-bahan tersebut murah dan siapapun bisa mencoba mengaplikasikan pestisida nabati.

\section{METODE PENELITIAN}

Percobaan dilaksanakan di Desa Pasawahan, Kecamatan Tarogong Kaler, Kabupaten Garut. Dengan ketinggian tempat 758 mdpl. Tipe curah hujan berdasarkan kriteria (Schmidt dan Ferguson, 1951) termasuk tipe curah hujan C dengan nilai $Q=48,6 \%$ yaitu agak basah. Percobaan dilaksanakan pada bulan Juni sampai September 2017.

Metode yang digunakan dalam penelitian ini adalah metode eksperimental dengan menggunakan Rancangan Acak Kelompok (RAK) pola faktorial $4 \times 3$ dengan 3 kali ulangan. Faktor perlakuan pertama Perlakuan konsentrasi (K) terdiri atas 4 taraf yaitu:

$\mathrm{k}_{1}=4 \mathrm{ml} /$ liter air

$\mathrm{k}_{2}=8 \mathrm{ml} / \mathrm{liter}$ air 
$\mathrm{k}_{3}=16 \mathrm{ml} / \mathrm{liter}$ air

$\mathrm{k}_{4}=32 \mathrm{ml} /$ liter air

Faktor kedua jenis pestisida (J) terdiri atas 3 taraf yaitu;

$\mathrm{j}_{1}=$ larutan ekstrak daun menngkudu

$\mathrm{j}_{2}=$ larutan ekstrak daun suren

$\mathrm{j}_{3}=$ larutan ekstrak daun pepaya.

Pengamatan dilakukan dengan mengamati komponen pengamatan utama: jumlah hama dan intensitas serangan. Pengamatan pertumbuhan dan hasil untuk mengetahui pengaruh setiap perlakuan diantaranya tinggi tanaman, jumlah daun, luas daun, bobot kering pertanaman, dan bobot per tanaman.

\section{HASIL DAN PEMBAHASAN}

\section{Tinggi Tanaman}

Hasil analisis ragam mengenai jumlah hama Plutella xylostella L. menunjukkan tidak terjadi interaksi antara konsentrasi dan jenis larutan pestisida nabati terhadap jumlah hama Plutella xylostella L. (Tabel 1).

Tabel 1. Pengaruh Berbagai Konsentrasi dan Jenis pestisida Nabati Jumlah Hama Plutella. xylostella L. Pada Kubis Ungu (Brassica oleracea) per plot.

\begin{tabular}{ll}
\hline \multicolumn{1}{c}{$\begin{array}{c}\text { Perlakuan } \\
\text { Konsentrasi }(\mathbf{K})\end{array}$} & Rata-Rata Jumlah Hama (\%) \\
\hline $\mathrm{k}_{1}=4 \mathrm{ml} / \mathrm{l}$ air & $4,26 \mathrm{~b}$ \\
$\mathrm{k}_{2}=8 \mathrm{ml} / \mathrm{l}$ air & $3,17 \mathrm{a}$ \\
$\mathrm{k}_{3}=16 \mathrm{ml} / \mathrm{l}$ air & $2,71 \mathrm{a}$ \\
$\mathrm{k}_{4}=32 \mathrm{ml} / \mathrm{l}$ air & $2,46 \mathrm{a}$ \\
\hline Jenis Ekstrak $(\mathrm{J})$ & \\
\hline $\mathrm{j}_{1}=$ daun mengkudu & $3,23 \mathrm{~b}$ \\
$\mathrm{j}_{2}=$ daun suren & $2,55 \mathrm{a}$ \\
$\mathrm{j}_{3}=$ daun pepaya & $3,67 \mathrm{c}$ \\
\hline
\end{tabular}

$\overline{\text { Keterangan : Angka rata-rata yang diikuti huruf yang sama pada setiap kolom, tidak }}$ berbeda nyata menurut Uji Jarak Berganda Duncan pada taraf 5\%.

Tabel 1 menunjukkan bahwa efek mandiri perlakuan pemberian konsentrasi pestisida nabati yang paling baik yaitu k4 konsentrasi $32 \mathrm{ml} / \mathrm{L}$ air komponen kimiawi yang terdapat pada konsentrasi tersebut telah bisa mempengaruhi populasi hama Plutella xylostella L. Hal ini terjadi semakin tinggi konsentrasi yang digunakan untuk perlakuan maka kandungan senyawa metabolit dalam ekstrak 
tersebut lebih banyak sehingga daya racunnya semakin tinggi dengan demikian kematian larva semakin banyak. Hal ini sesuai dengan pendapat Priyono (1994) dalam Marhaeni (2001), bahwa semakin tinggi konsentrasi yang digunakan, maka kandungan bahan aktif dalam larutan lebih banyak sehingga daya racun pestisida nabati semakin tinggi. Semakin tinggi daya racun menyebabkan kematian larva semakin banyak. Peningkatan persentase mortalitas larva dengan semakin tingginya konsentrasi ekstrak selain karena besarnya kadar bahan aktif yang bersifat toksik juga diduga karena kurangnya nutrisi yang dikonsumsi oleh larva akibat adanya senyawa antimakan dalam ekstrak. Senyawa-senyawa tersebut meliputi triterpenoid dan tanin. Hal ini menunjukkan bahwa semakin tinggi konsentrasi yang digunakan untuk perlakuan maka kandungan senyawa metabolit dalam ekstrak tersebut lebih banyak sehingga diduga ekstrak tersebut mempunyai sifat antifeedan semakin tinggi, dengan demikian aktivitas makan larva semakin menurun.

\section{Intensitas Serangan Hama Plutella xylostella $\mathrm{L}$}

Hasil analisis ragam mengenai intensitas serangan menunjukan tidak terjadi interaksi antara konsentrasi dan jenis larutan pestisida nabati terhadap jumlah hama Plutella xylostella L. per plot. Analisis selengkapnya terdapat pada Lampiran 4 dan hasil analisis dapat disajikan pada (Tabel 2).

Efek mandiri perlakuan pemberian pestisida nabati, sesuai taraf faktor konsentrasi larutan pestisida nabati menunjukan tidak berbeda nyata terhadap intensitas serangan hama Plutella xylostella L, di sebabkan setiap konsentrasi memiliki kemampuan untuk membunuh dan menghambat serangan hama Plutella xylostella L.

Tabel 2. Intensitas Serangan Hama Ulat Plutella xylostella L. Pada Tanaman Kubis

\begin{tabular}{lc}
\hline \multicolumn{1}{c}{$\begin{array}{c}\text { Perlakuan } \\
\text { Konsentrasi ( K ) }\end{array}$} & Rata-Rata Intensitas Serangan (\%) \\
\hline $\mathrm{k}_{1}=4 \mathrm{ml} / \mathrm{l}$ air & $70,16 \mathrm{a}$ \\
$\mathrm{k}_{2}=8 \mathrm{ml} / \mathrm{l}$ air & $63,63 \mathrm{a}$ \\
$\mathrm{k}_{3}=16 \mathrm{ml} / \mathrm{l}$ air & $58,33 \mathrm{a}$ \\
$\mathrm{k}_{4}=32 \mathrm{ml} / \mathrm{l}$ air & $53,71 \mathrm{a}$ \\
\hline Jenis Ekstrak $\mathbf{~} \mathbf{~}$ ) & $61,62 \mathrm{~b}$ \\
\hline $\mathrm{j}_{1}=$ daun mengkudu & $52,49 \mathrm{a}$ \\
$\mathrm{j}_{2}=$ daun suren & $70,27 \mathrm{~b}$ \\
$\mathrm{j}_{3}=$ daun pepaya & \\
\hline Keterangan : Angka rata-rata yang diikuti huruf yang sama pada kolom yang \\
\multicolumn{2}{c}{ sama, berbeda tidak nyata menurut Uji Jarak Berganda Duncan pada } \\
taraf 5\%.
\end{tabular}




\section{Pengamatan Pertumbuhan dan Hasil}

\section{Tinggi Tanaman}

Hasil analisis ragam mengenai tinggi tanaman pada umur 15, 30, dan 45 HST. Hasil analisis ragam menunjukan tidak terjadi interaksi. Untuk lebih jelasnya hasil analisis data rata-rata tinggi tanaman terdapat pada tabel 3.

Tabel 3. Tinggi Tanaman

\begin{tabular}{lccc}
\hline \multirow{2}{*}{ Perlakuan } & \multicolumn{3}{c}{ Rata-Rata Tinggi Tanaman $(\mathbf{c m})$} \\
\cline { 2 - 4 } & $\mathbf{1 5} \mathbf{H S T}$ & 30 HST & 45 HST \\
\hline Konsentrasi $(\mathrm{K})$ & & & \\
$\mathrm{k}_{1}=4 \mathrm{ml} / \mathrm{l}$ air & $8,79 \mathrm{a}$ & $20,51 \mathrm{a}$ & $20,51 \mathrm{a}$ \\
$\mathrm{k}_{2}=8 \mathrm{ml} / \mathrm{l}$ air & $8,43 \mathrm{a}$ & $22,69 \mathrm{a}$ & $22,69 \mathrm{a}$ \\
$\mathrm{k}_{3}=16 \mathrm{ml} / \mathrm{l}$ air & $8,58 \mathrm{a}$ & $22,98 \mathrm{a}$ & $22,98 \mathrm{a}$ \\
$\mathrm{k}_{4}=32 \mathrm{ml} / 1$ air & $8,92 \mathrm{a}$ & $20,99 \mathrm{a}$ & $20,99 \mathrm{a}$ \\
\hline Jenis Pestisida $(\mathrm{J})$ & & & \\
$\mathrm{j}_{1}=$ daun mengkudu & $8,76 \mathrm{a}$ & $21,56 \mathrm{a}$ & $21,56 \mathrm{a}$ \\
$\mathrm{j}_{2}=$ daun suren & $8,76 \mathrm{a}$ & $21,56 \mathrm{a}$ & $21,56 \mathrm{a}$ \\
$\mathrm{j}_{3}=$ daun pepaya & $8,76 \mathrm{a}$ & $21,56 \mathrm{a}$ & $21,56 \mathrm{a}$ \\
\hline
\end{tabular}

Keterangan : Angka rata-rata yang diikuti huruf yang sama pada kolom yang sama, berbeda tidak nyata menurut Uji Jarak Berganda Duncan pada taraf $5 \%$.

Tabel 3 menunjukan efek mandiri faktor perlakuan konsentrasi, semua taraf faktor menunjukan pengaruh tidak berbeda nyata terhadap tinggi tanaman. Hal tersebut diduga bahwa perlakuan konsentrasi tidak berpengaruh langsung terhadap tinggi tanaman, karena hama kabanyakan menyerang jaringan daun bagian bawah dengan hanya meninggalkan bagian epidermis bagian atas daun. Untuk setiap tanaman di berikan perlakuan yang sama di antaranya pemberian dosis pupuk yang sama, penyiraman, penyiangan, dan pemelihraan.

Efek mandiri faktor perlakuan jenis menunjukan tidak berbeda nyata pada setiap faktor. Dikarenakan pestisida nabati tidak terlalu berpengaruh pada setiap tinggi tanaman dan pada setiap tanaman.

\section{Jumlah Daun}

Hasil analisis ragam menunjukkan tidak terjadi interaksi antara konsentrasi dengan jenis larutan pestisida nabati terhadap jumlah daun pada umur 15, 30 dan 45 HST. Untuk lebih jelasnya hasil analisis data rata-rata jumlah daun terlihat pada Tabel 4.

Menurut Rahmat Rukmana (1997), P. xylostella sebagai hama tanaman kubis, merusak tanaman pada stadium larva. Larva yang baru menetas akan menyerap ke permukaan daun dan melubangi epidermis atau daging daun. Pada 
umumnya larva memakan permukaan daun bagian atas, dan tidak menyerang titik tumbuh, sehingga tidak mempengaruhi pembentukan daun.

Tabel 4. Jumlah Daun Per Tanaman

\begin{tabular}{lccc}
\hline \multicolumn{1}{c}{ Perlakuan } & \multicolumn{3}{c}{ Rata-Rata Jumlah Daun } \\
\cline { 2 - 4 } & 15 HST & 30 HST & 45 HST \\
\hline Konsentrasi (K) & $6,58 \mathrm{a}$ & $16,36 \mathrm{a}$ & $17,06 \mathrm{a}$ \\
$\mathrm{k}_{1}=4 \mathrm{ml} / \mathrm{l}$ air & $6,61 \mathrm{a}$ & $15,92 \mathrm{a}$ & $15,97 \mathrm{a}$ \\
$\mathrm{k}_{2}=8 \mathrm{ml} / \mathrm{l}$ air & $7,22 \mathrm{a}$ & $16,53 \mathrm{a}$ & $14,75 \mathrm{a}$ \\
$\mathrm{k}_{3}=16 \mathrm{ml} / \mathrm{l}$ air & $6,92 \mathrm{a}$ & $16,72 \mathrm{a}$ & $17,11 \mathrm{a}$ \\
$\mathrm{k}_{4}=32 \mathrm{ml} / \mathrm{l}$ air & & & \\
Jenis Pestisida $(\mathrm{J})$ & $6,98 \mathrm{a}$ & $16,00 \mathrm{a}$ & $15,92 \mathrm{a}$ \\
$\mathrm{j}_{1}=$ daun mengkudu & $6,98 \mathrm{a}$ & $17,63 \mathrm{a}$ & $16,75 \mathrm{a}$ \\
$\mathrm{j}_{2}=$ daun suren & $6,54 \mathrm{a}$ & $15,52 \mathrm{a}$ & $16,00 \mathrm{a}$ \\
$\mathrm{j}_{3}=$ daun pepaya & \multicolumn{4}{c}{. } &
\end{tabular}

\section{Luas Daun per Tanaman}

Hasil analisis ragam menunjukkan tidak terjadi interaksi antara konsentrasi dengan jenis larutan pestisida nabati terhadap luas daun per tanaman hasil analisis dapat dilihat pada Tabel 5.

Berdasarkan hasil penelitian dapat dikemukakan bahwa perlakuan j2 ekstrak daun suren dapat berpengaruh berbeda nyata terhadap luas daun per tanaman. Hal ini disebabkan serangan hama Plutella xylostella L. menyerang bagian daun dan menyisakan tulang daunnya saja. Menurut Permadani dan Sastrosiswojo (1993) bila tingngkat serangan tinggi, atau hama pesaingnya Crocidolomia binotalis tidak ada, Plutella xylostella $L$. akan menyerang krop kubis dan merusak berat pada daun sering terjadi. Hampir seluruh daun dimakan larva dan tinggal hanya tulang-tulang daun dan akan mempengaruhi luas daun per tanaman.

Menurut Kelik (2010), parameter luas daun ini dapat memberi gambaran tentang proses dan laju fotosintesis pada suatu tanaman, yang pada akhirnya berkaitan dengan pembentukan biomassa tanaman. Menurut Ratna (2002), peningkatan luas daun merupakan upaya tanaman dalam mengefisiensikan penangkapan energi cahaya untuk fotosintesis secara normal pada kondisi intensitas cahaya rendah. 
Tabel 5. Hasil Polong Per Plot

\begin{tabular}{lc}
\hline \multicolumn{1}{c}{$\begin{array}{c}\text { Perlakuan } \\
\text { Konsentrasi }(\mathbf{K})\end{array}$} & Rata-Rata Luas Daun $\left(\mathbf{c m}^{2}\right)$ \\
\hline $\mathrm{k}_{1}=4 \mathrm{ml} / \mathrm{l}$ air & $1198,67 \mathrm{~b}$ \\
$\mathrm{k}_{2}=8 \mathrm{ml} / \mathrm{l}$ air & $1105,33 \mathrm{a}$ \\
$\mathrm{k}_{3}=16 \mathrm{ml} / \mathrm{l}$ air & $1134,67 \mathrm{a}$ \\
$\mathrm{k}_{4}=32 \mathrm{ml} / \mathrm{l}$ air & $1620,00 \mathrm{c}$ \\
\hline Jenis Ekstrak $(\mathrm{J})$ & \\
$\mathrm{j}_{1}=$ daun mengkudu & $1309,00 \mathrm{~b}$ \\
$\mathrm{j}_{2}=$ daun suren & $1563,00 \mathrm{c}$ \\
$\mathrm{j}_{3}=$ daun pepaya & $922,00 \mathrm{a}$ \\
\hline
\end{tabular}

Keterangan : Angka rata-rata yang diikuti hurup yang samapada setiap kolom tidak berbeda nyata pada taraf 5\% berdasarkan Uji Jarak Berganda Duncan.

\section{Bobot Kering Tanaman}

Hasil analisis ragam menunjukkan tidak terjadi interaksi antara konsentrasi dengan jenis larutan pestisida nabati terhadap bobot kering per tanaman hasil analisis disajikan pada Tabel 6.

Tabel 6 menunjukan efek mandiri faktor perlakuan konsentrasi dan jenis pestisida nabati, taraf faktor menunjukan pengaruh berbeda nyata terhadap bobot kering tanaman k1, k2, k3, berbeda nyata dengan k4, demikian pula efek mandiri faktor perlakuan jenis pestisida nabati menunjukan taraf faktor $\mathrm{j} 2$ berbeda nyata debgan taraf faktor j1 dan $\mathrm{j} 3$.

Tabel 6. Bobot Kering per Tanaman

Perlakuan

Konsentrasi (K)

\begin{tabular}{ll}
\hline $\mathrm{k}_{1}=4 \mathrm{ml} / \mathrm{l}$ air & $28,69 \mathrm{a}$ \\
$\mathrm{k}_{2}=8 \mathrm{ml} / \mathrm{l}$ air & $30,51 \mathrm{a}$ \\
$\mathrm{k}_{3}=16 \mathrm{ml} / \mathrm{l}$ air & $32,62 \mathrm{a}$ \\
$\mathrm{k}_{4}=32 \mathrm{ml} / \mathrm{l}$ air & $53,24 \mathrm{~b}$ \\
\hline Jenis Ekstrak $(\mathrm{J})$ & \\
$\mathrm{j}_{1}=$ daun mengkudu & $29,07 \mathrm{a}$ \\
$\mathrm{j}_{2}=$ daun suren & $48,54 \mathrm{~b}$ \\
$\mathrm{j}_{3}=$ daun pepaya & $31,19 \mathrm{a}$ \\
\hline
\end{tabular}

Keterangan : Angka rata-rata pada perlakuan yang diikuti huruf yang sama tidak berbeda nyata pada taraf 5\% berdasarkan Uji Jarak Berganda Duncan.

\section{Bobot Tanaman}

Hasil analisis ragam menunjukkan tidak terjadi interaksi antara konsentrasi dengan jenis larutan pestisida nabati terhadap bobot per tanaman. 
Analisis selengkapnya terdapat pada Lampiran 12, dan hasil analisis disajikan pada Tabel 7.

Tabel 7 menunjukan efek mandiri faktor perlakuan konsentrasi tidak berbeda nyata terhadap bobot tanaman dan jenis pestisida nabati, semua taraf faktor menunjukan pengaruh tidak berbeda nyata terhadap bobot tanaman. Hasil pengamatan bisa di sajikan di bawah ini :

Tabel 7. Bobot Tanaman

\begin{tabular}{lc}
\hline \multicolumn{1}{c}{$\begin{array}{c}\text { Perlakuan } \\
\text { Konsentrasi }(\mathbf{K})\end{array}$} & Rata-Rata Bobot Tanaman $(\mathbf{g})$ \\
\hline $\mathrm{k}_{1}=4 \mathrm{ml} / \mathrm{l}$ air & $154,72 \mathrm{a}$ \\
$\mathrm{k}_{2}=8 \mathrm{ml} / \mathrm{l}$ air & $160,78 \mathrm{a}$ \\
$\mathrm{k}_{3}=16 \mathrm{ml} / \mathrm{l}$ air & $225,56 \mathrm{a}$ \\
$\mathrm{k}_{4}=32 \mathrm{ml} / \mathrm{l}$ air & $199,56 \mathrm{a}$ \\
\hline Jenis Ekstrak $(\mathrm{J})$ & \\
$\mathrm{j}_{1}=$ daun mengkudu & $200,00 \mathrm{a}$ \\
$\mathrm{j}_{2}=$ daun suren & $236,83 \mathrm{a}$ \\
$\mathrm{j}_{3}=$ daun pepaya & $118,63 \mathrm{a}$ \\
\hline
\end{tabular}

Keterangan : Angka rata-rata pada perlakuan yang diikuti huruf yang sama tidak berbeda nyata pada taraf $5 \%$ berdasarkan Uji Jarak Berganda Duncan.

\section{KESIMPULAN}

Berdasarkan hasil penelitian pengaruh konsentrasi dan ekstrak daun tumbuhan sebagai pestisida nabati terhadap hama ulat Plutella xylostella L. pada tanaman kubis ungu, dapat disimpulkan :

1. Tidak terjadi interaksi antara konsentrasi dengan jenis ekstrak daun tumbuhan sebagai pestisida nabati terhadap hama ulat Plutella xylostella L. pada tanaman kubis ungu.

2. Kombinasi perlakuan $\mathrm{k} 4 \mathrm{j} 2$ berpengaruh baik terhadap penekanan jumlah populasi hama dan intensitas serangan hama ulat Plutella xylostella L., dan hasil bobot krop pertanaman, tetapi efektifitasnya masih rendah.

\section{DAFTAR PUSTAKA}

Kishi, m., n. Hirschhorn, m. Djajadisastra, 1.n. satterlee, s. Strowman and r. Dilts. 1995. Relationship of pesticide spraying to signs and symptoms in Indonesian farmers. Scand J. Work Environ. Health 21(2): 124- 133. 
Marhaeni KS. 2001. Pengaruh Beberapa Konsentrasi Ekstrak Biji Sirsak (Annona muricata L.) terhadap Perkembangan Spodoptera litura (Lepidoptera, Noctuidae). Skripsi. Tidak Dipublikasikan. Surabaya: UPN

Muhlisah, F. 2001. Tanaman Obat Keluarga. Jakarta: Penebar Swadaya. Permadani, A. H dan S. Sastrosiswojo,1993. Kubis. Balai Penelitian Holtikultura Lembang.

Ratna, DI. 2002. Pengaruh Kombinasi Konsentrasi Pupuk Hayati dengan Pupuk Organik Cair Terhadap Kualitas dan Kuantitas Hasil Tanaman Teh (Camellia sinensis L.) O.Kuntze) Klon Gambung 4. Jurnal Ilmu Pertanian 10: $17-25$.

Regina Tutik Padmaningrum dan Das Salirawati. 2007. Pengembangan Prosedur Penentuan Kadar Asam Cuka secara Titrasi Asam Basa dengan Berbagai Indikator Alami(Sebagai Alternatif Praktikum Titrasi Asam Basa di SMA, Laporan Penelitian, FMIPA UNY: Yogyakarta.

Rukmana. R. 1997. Teknik Pengendalian Hama dan Penyakit Tanaman. Kanisus. Yogyakarta 7677p. 